Survey of Greenland, Denmark) for his help during the work. Age standards were supplied by C. W. Naeser (USGS Denver, USA) and A. J. W. Gleadow (University of Melbourne, Australia). Corning glasses were supplied by Corning Glass Works, USA. C. K. Brooks (University of Copenhagen, Denmark) and F. Surlyk (Geological Survey of Greenland) contributed valuable comments on the manuscript.

\section{References}

Gleadow, A. J. W. \& Brooks, C. K. 1979: Fission track dating, thermal histories and tectonics of igneous intrusions in East Greenland. Contr. miner. Petrol. 71, 45-60.

Gleadow, A. J. W., Duddy, I. R. \& Lovering, J. F. 1983: Fission track analysis: a new tool for evaluation of thermal histories and hydrocarbon potential. J. Aust. Petrol. Explor. Ass. 23, 93-102.

Gleadow, A. J. W., Duddy, I. R., Green, P. F. \& Lovering, J. F. 1986: Confined fission track lengths in apatite: a diagnostic tool for thermal history analysis. Contr. miner. Petrol. 94, 405-415.

Hansen, B. T. \& Steiger, R. H. 1971: The geochronology of the Scoresby Sund area 1: Rb-Sr mineral ages. Rapp. Gronlands geol. Unders. 37, 55-57.
Hansen, K. 1985: Fission track age determinations of vertical movements in the crust caused by continental rifting: A fission track age study of the Scoresby Sund area; method and results. Unpublished thesis, Univ. Copenhagen, 119 pp.

Hurford, A. J. \& Green, P. F. 1983: The zeta age calibration of fission track dating. Isotope Geosci. 1, 285-317.

Surlyk, F., Hurst, J. M., Piasecki, S., Rolle, F., Scholle, P. A., Stemmerik, L. \& Thomsen, E. 1986: The Permian of the western margin of the Greenland Sea - A future exploration target. In Halbouty, M. T. (edit.) Future petroleum provinces of the world. Mem. Am. Ass. Petrol. Geol. 40, 629659.

Watt, W. S., Larsen, L. M. \& Watt, M. 1986: Volcanic history of the lower Tertiary plateau basalts in the Scoresby Sund region, East Greenland. Rapp. Grønlands geol. Unders. 128, 147-156.

\title{
Studies of the onshore hydrocarbon potential in East Greenland 1986-87: field work from $73^{\circ}$ to $76^{\circ} \mathrm{N}$
}

\author{
C. Marcussen, P.-H. Larsen, H. Nøhr-Hansen, H. Olsen, \\ S. Piasecki and L. Stemmerik
}

The study of the Devonian to Cretaceous sequence in central and northern East Greenland was continued in 1987. Field work was carried out from early July to mid August covering the region between Ymer $\emptyset$ and Hochstetter Forland (fig. 1). This was the second year of a two-year field work programme (Marcussen et al., 1987) which forms part of a regional programme comprising sedimentological, stratigraphic, structural, and petroleum geological studies of the sedimentary basin in central East Greenland (e.g. Surlyk, 1983; Surlyk et al., 1984, 1986a,b).

Stordal in Hudson Land, which offers a natural landing strip for STOL aircraft, was used as base camp for the 1987 expedition. The expedition group of 15 included four to five geological field parties and five supporting personnel, including a helicopter pilot and mechanic. In addition a five-man British-Danish East Greenland 'vertebrate-paleontological' expedition (Bendix-Almgreen, 1988) and a group from GGU plan- ning the 1988 expedition to North-East Greenland were present. Two teams (led by P.-H, Larsen and H. Olsen) studied the tectonics and sedimentology of the Devonian succession. Two teams (led by L. Stemmerik and S. Piasecki) investigated the Carboniferous, Permian and Triassic sedimentology of the region. The Jurassic and Cretaceous sequences were studied by two teams (led by S. Piasecki and in the late half of the season by $\mathrm{H}$. Nøhr-Hansen). All the teams collected material for source rock analyses and a large number of samples were also collected for determining reservoir rock properties.

\section{Devonian}

Sedimentological studies. The field work in 1987 was concentrated on Ymer $\emptyset$, Gauss Halv $\varnothing$, Moskusokselandet and Strindberg Land (figs 1, 2). Detailed facies analyses were made by vertical facies logging and 2- 


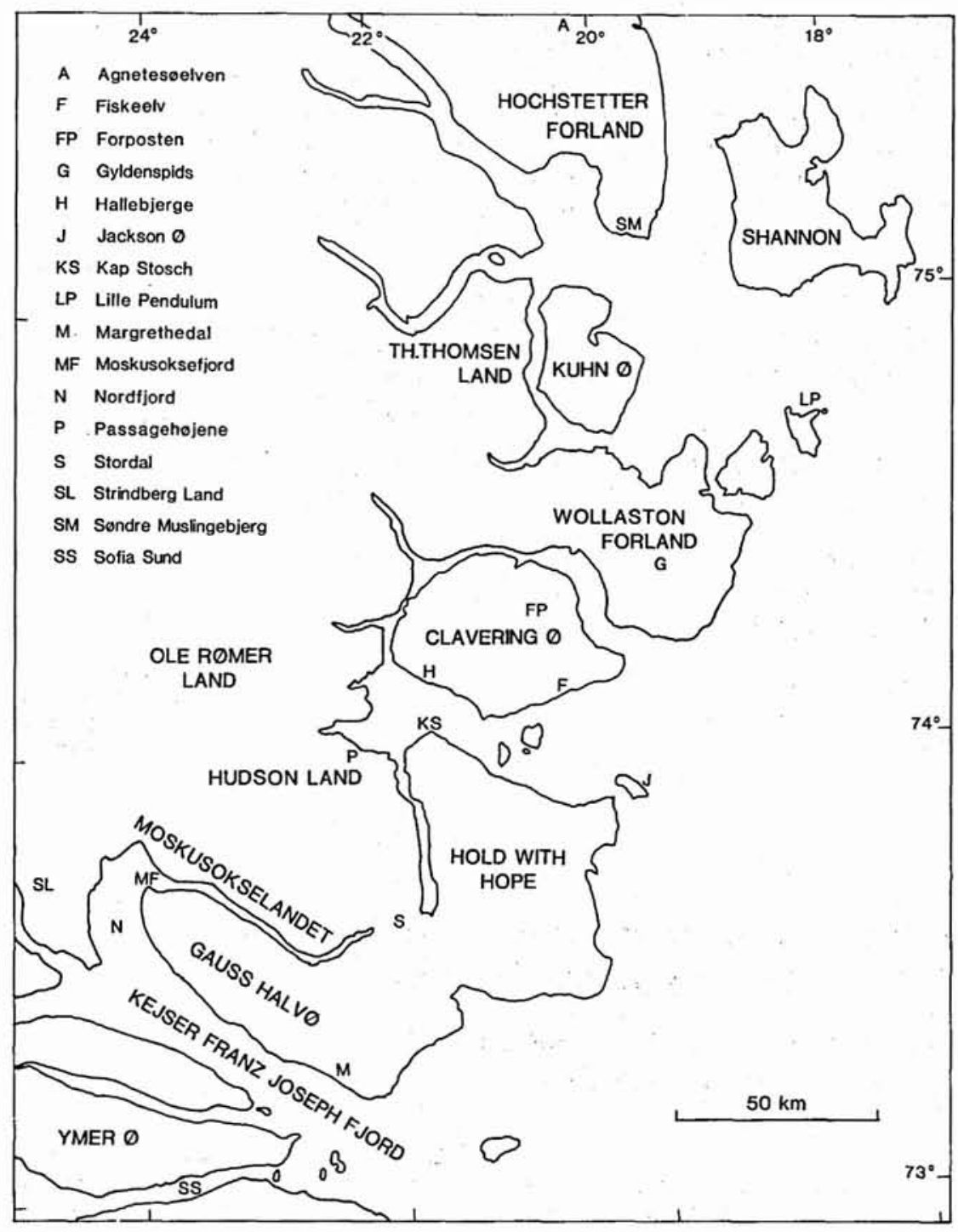

Fig. 1. The study area with localities mentioned in text.

dimensional facies mapping in the Middle to Upper Devonian Kap Kolthoff Supergroup (Friend et al., 1983). Sandy braidplain deposits, alluvial fan conglomerates and windblown sandstones were present. The Upper Devonian Kap Graah Group (Friend et al., 1983) was studied in detail in Ymer $\emptyset$ and Gauss Halvø. By facies association mapping, a stratigraphic subdivision of the formerly undivided group was attempted. Facies analysis of meandering stream deposits implies an asymmetric development of the point bar deposits which may be controlled by tectonics. Similarly an asymmetric distribution of facies associations and palaeocurrent directions seemed to indicate a tectonic influence on the depositional environments. The Upper Devonian Mt. Celcius Supergroup (Friend et al., 1983) was briefly studied on Stensiö Bjerg, Gauss Halvø. Facies associ- ations were logged and two black shale units of potential source quality, $1 \mathrm{~m}$ and $5 \mathrm{~m}$ thick, were sampled in detail for analytical work.

Structural studies. The structural investigations in the Devonian outcrop area were concentrated on Moskusokselandet, Ole Rømer Land, Hudson Land and Ymer $\varnothing$ (figs 1,2 ). Selected areas and meso-structures were mapped on aerial photographs (1:50 000), while larger structures were studied by reconnaissance work supported by helicopter.

The coastal cliffs of Sofia Sund, Kejser Franz Joseph Fjord, Nordfjord and Moskusoksefjord were photographed by Jacob Lautrup. These coast panoramas together with new aerial photographs taken by the Geodetic Institute in 1987 (1:150 000) will be important 
Fig. 2. Geological map of the study area. Simplified after Koch \& Haller (1971) with minor revisions based on Surlyk (1978b) and 1987 field work.

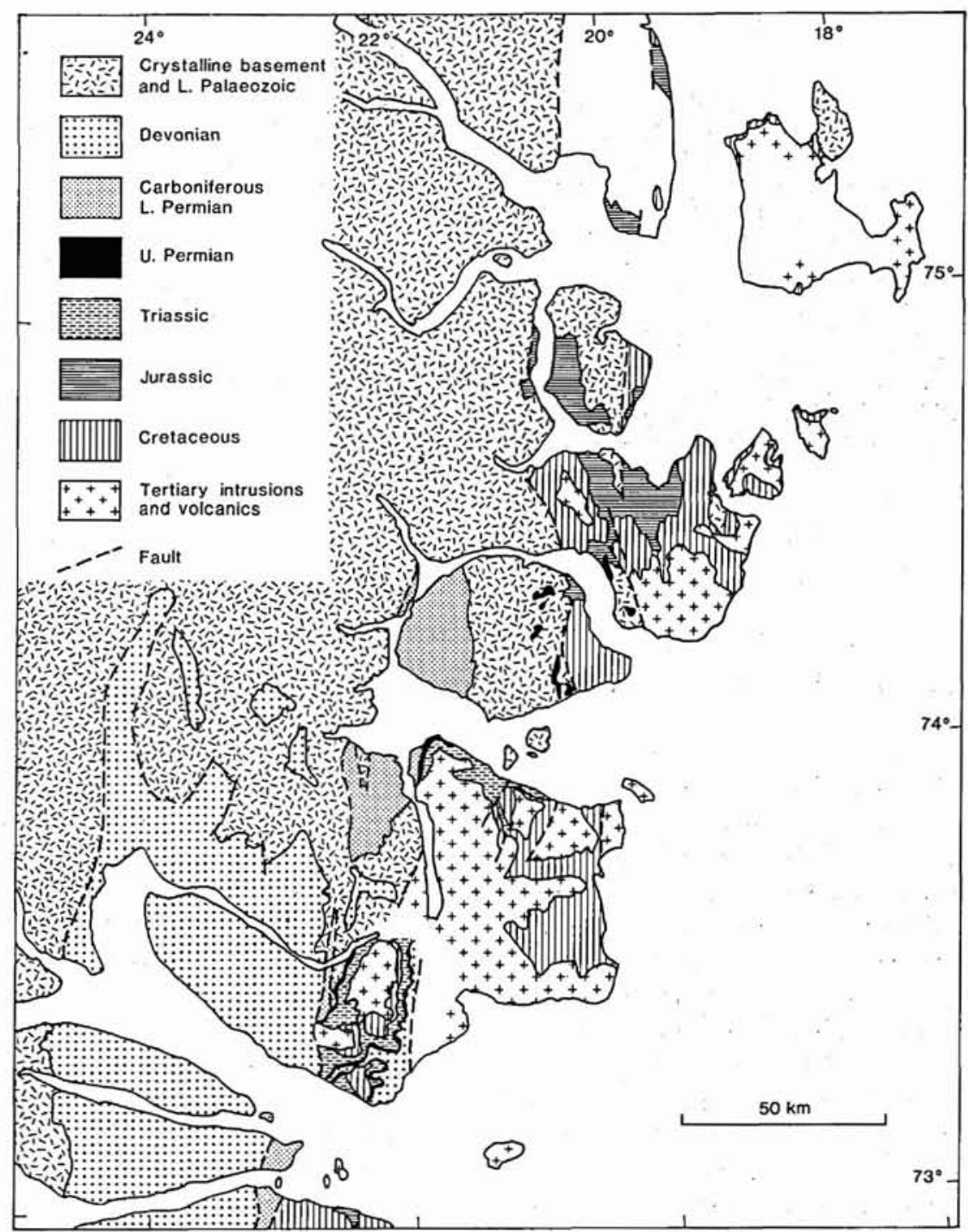

tools in the continued structural work. According to Bütler (1959) the structural style is dominated by thrusting and folding in various synsedimentary phases, the Hudson Land phases, resulting in angular disconformities and breaks in the sedimentation. The present work has shown that these deformations are local in character reflecting the sedimentological evolution in local parts of the basin, but not necessarily in the entire basin. In Carboniferous time the area was deformed during the Ymer $\emptyset$ phase of Bütler (1959). This deformation especially affected the southern part of the basin and the 1987 work shows that the deformation here caused the development of low-angle thrusts and ramp anticlines in a contractional thin-skinned tectonic environment (fig. 3). Some attention was paid to the granitic 'Moskusokselandet Inlier' which Bütler (1959) suggests was devel- oped during the Devonian. Eleven samples were collected for radiometric dating $(\mathrm{Rb} / \mathrm{Sr})$ to investigate the timing of the granitic emplacement within the inlier. Collection of fossil plant material from the Devonian sandstones was continued this year. The state of preservation is rather poor and preliminary investigation of the material by Dianne Edwards, University College, Cardiff, Wales, has not yet yielded any new stratigraphic information.

\section{Carboniferous}

Sediments of Carboniferous age were studied briefly around Moskusoksefjord and Passagehøjene, and in some detail in Hallebjerge, western Clavering $\varnothing$ (figs 1 , 2). Tentatively, this more than $600 \mathrm{~m}$ thick succession is 


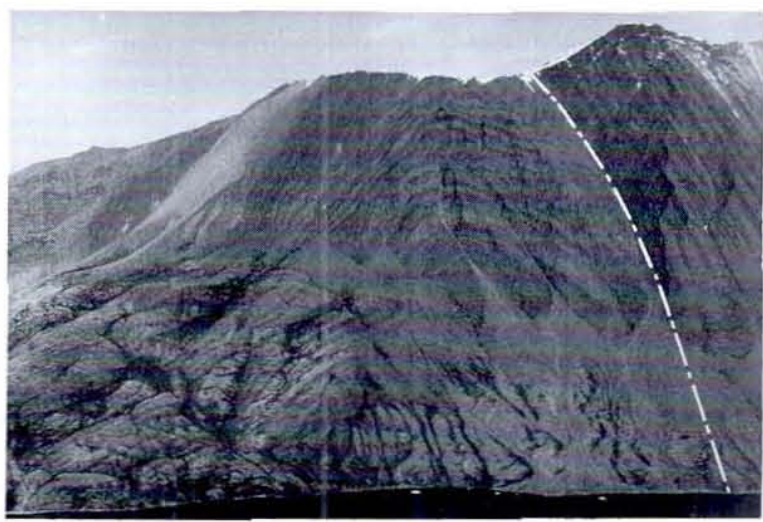

Fig. 3. Devonian sandstone forming a huge box-fold which to the east is overridden by a thrust. Rødebjerg at the south coast of Ymer $\varnothing$. Height of cliff is approximately $1600 \mathrm{~m}$.

correlated with the lowermost of the three units described from the Traill $\varnothing$ - Ymer $\emptyset$ area by Marcussen et al. (1987).

The succession is dominated by fluviatile sandstones. Malmquist (1932) and Säve-Söderbergh (1934) subdivided the succession at Hallebjerge and Passagehøjene, respectively, based on the different colour of the sandstones and the content of the conglomerates.

The present study indicates that fine-grained, shaly deposits are more widespread than previously assumed. The recovery at western Clavering $\varnothing$ of two shaly sequences in the lower red sandstone unit of Malmquist (1932) may be of interest as potential source rocks. The $15-20 \mathrm{~m}$ thick shaly sequences yield abundant ostracods and are thought to be of lacustrine origin. Lacustrine shales of Carboniferous age with a fair to good sourcerock potential are known from several locations further to the south and suggest that the Clavering $\varnothing$ shales may hold similar source-rock quantities.

\section{Upper Permian - Lower Triassic}

The outcrops of Upper Permian - Lower Triassic sediments in the northern part of the basin are geographically subdivided into three regions: Gauss Halvø, Kap Stosch and eastern Clavering Ø. (figs 1,2). These regions were investigated in detail for sedimentology, stratigraphy, thermal maturity and source-rock analyses. The lithological subdivision of the Upper Permian sequence, the Foldvik Creek Group, employed by Surlyk et al. (1986a) in the Jameson Land region, appears to be applicable to the complete region with only minor adjustments.

The basal Upper Permian Huledal Formation is deposited unconformably on a variety of substrata in- cluding crystalline basement, post-Caledonian intrusions, Devonian and Carboniferous sediments. The thickness depends on local topography and differentiated subsidence of the substratum and varies from 0 to more than $100 \mathrm{~m}$. The overlying Karstryggen Formation is 5 to more than $30 \mathrm{~m}$ thick and consists of a variety of hypersaline shallow marine limestones and evaporites. Preliminary investigations suggest that deposition took place in environments similar to those described from the formation in Jameson Land (Surlyk et al., 1986a).

The Karstryggen Formation is overlain by normal marine limestone of the Wegener Halvø Formation along the western margin of the basin, particularly in north-eastern Clavering $\varnothing$, and by scattered outcrops in southern Wollaston Forland. The formation is mainly composed of bedded biogene limestone of probable reef flank origin. However, in situ reefs or mounds were not found in this less than $60 \mathrm{~m}$ thick carbonate sequence. Laterally to the east, shales of the Ravnefjeld Formation were deposited.

The Ravnefjeld Formation, formerly Posidonia Shale, occurs throughout the region. The maximum thickness appears to be 15 to $20 \mathrm{~m}$. Maync (1942) indicated $70 \mathrm{~m}$ of 'Posidonia Shale' from Fiskeelv on Clavering $\emptyset$, but due to scree cover of the section, no precise measurement of the thickness is possible; however, the estimated thickness is about $20 \mathrm{~m}$ rather than the $70 \mathrm{~m}$ suggested by Maync (1942). The Ravnefjeld Formation is generally reduced in thickness to a few metres near carbonate buildups at the western margin of the basin. The Ravnefjeld Formation may be subdivided into a lower grey, bioturbated siltstone with calcareous beds and an upper black, laminated silty shale with intervals of laminated, graded or massive carbonate beds and high concentrations of Posidonia permica. The lower unit is generally less than $5 \mathrm{~m}$ in thickness but exceptionally a thickness of $25 \mathrm{~m}$ was measured at the north side of Forposten, Clavering $\varnothing$. This lower unit is not known in the outcrops in Jameson Land. However, the upper part, the traditional 'Posidonia Shale', is very similar in the northern region to the outcrops in Jameson Land except for the presence of a rich nektonic vertebrate fauna which is especially confined to the calcareous intervals (Nielsen, 1935).

The overlying shale of the Schuchert Dal Formation is relatively calcareous compared to the southern region. The shale, tentatively included in the Oksedal Member, may be subdivided into a lower unit of calcareous silty shale and/or massive carbonate beds (formerly 'Martinia Limestone') and an upper unit of grey, green to red calcareous siltstone which consistently forms the top of the Upper Permian sequence. Carbonate debris flows (formerly 'Productus Limestone') rich in brachiopods, 
Fig. 4. Erosive channels filled with giant cross-bedded sandstone and conglomerates. Wordie Creek Formation, Kap Stosch. Height of lower sandstone unit is approximately $25 \mathrm{~m}$.

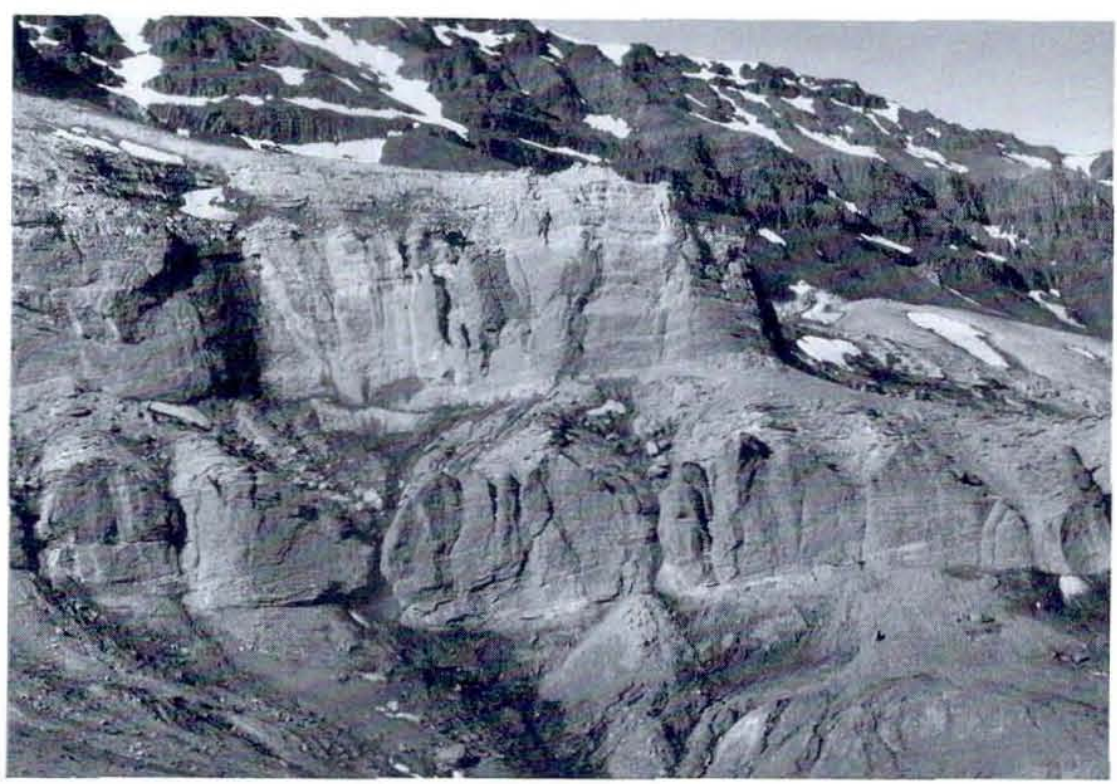

bryozoans and gastropods, occur scattered throughout.

The Lower Triassic Wordie Creek Formation follows the Upper Permian succession with a sharp boundary most likely representing a depositional break. However, in most cases, Triassic sediments conformably overlie the Permian sequence without any significant erosion in between. The earliest Triassic sediments are siltstone and conglomerates with coarse- to fine-grained sandstone. Higher in the sequence fine-grained wavy-bedded to lenticular sandstones alternate with red, brown and green siltstone. Six horizons of sandstone in the upper silty sequence transform laterally into deep erosional channels filled with sandstone and conglomerates. Giant epsilon cross bedding (fig. 4) can be seen within these channels.

\section{Jurassic-Cretaceous}

The Jurassic-Cretaceous succession is widely exposed particularly in the eastern part of the area (fig. 2). It overlies unconformably Caledonian to Triassic rocks and is covered by Tertiary plateau basalts (fig. 2).

The aim of the field work in the Jurassic-Cretaceous sequence was to obtain samples of material for stratigraphical, source potential and maturity studies. In order to understand the regional maturity pattern, sampling in large areas in the eastern part of the region, including Hold with Hope, Clavering $\varnothing$, Lille Pendulum, Shannon, Hochstetter Forland (figs 1, 2) was carried out during a helicopter reconnaissance programme.

The Middle Jurassic Vardekløft Formation was stud- ied in some detail in Hochstetter Forland, Wollaston Forland and Th. Thomsen Land (fig. 1). Material from the type section of the Muslingebjerg Member (Surlyk, 1977) at Søndre Muslingebjerg (fig. 1) and a previously poorly known section of the Pelion Member at Agnetesøelven (fig. 1) may be particularly important in understanding the Middle Jurassic stratigraphy.

The overlying dark silty shale of the Upper Jurassic Bernbjerg Formation and the syntectonic sediments of the Upper Jurassic - Lower Cretaceous Wollaston Forland Group (Surlyk, 1978a) were sampled intensively.

The Mesozoic succession is terminated by a more than $500 \mathrm{~m}$ thick transgressive sequence of dark silty shale with streaked and cross-bedded sandy horizons in the upper part. The shales overlie unconformably Upper Permian - Lower Cretaceous sediments. They are poorly dated as Aptian - Albian on the basis of very scattered macrofossils (Maync, 1949). Therefore, a systematic palynological sampling programme was carried out to establish a biostratigraphical zonation. However, Tertiary sills preferentially intrude these shales and may have altered the organic material in much of the area. It is hoped that analyses will show that well preserved sections are found on the north and east coast of Hold with Hope, Jackson $\varnothing$, Clavering $\varnothing$, Kuhn $\varnothing$ and several places in Wollaston Forland.

The thickness of the Albian - Aptian sequence varies from 25 to $115 \mathrm{~m}$ in Kuhn $\varnothing$ to more than $500 \mathrm{~m}$ at the mountain Gyldenspids (fig. 1) in Wollaston Forland. Further to the south on Hold with Hope and Gauss Halvø the thickness is approximately $400 \mathrm{~m}$. 


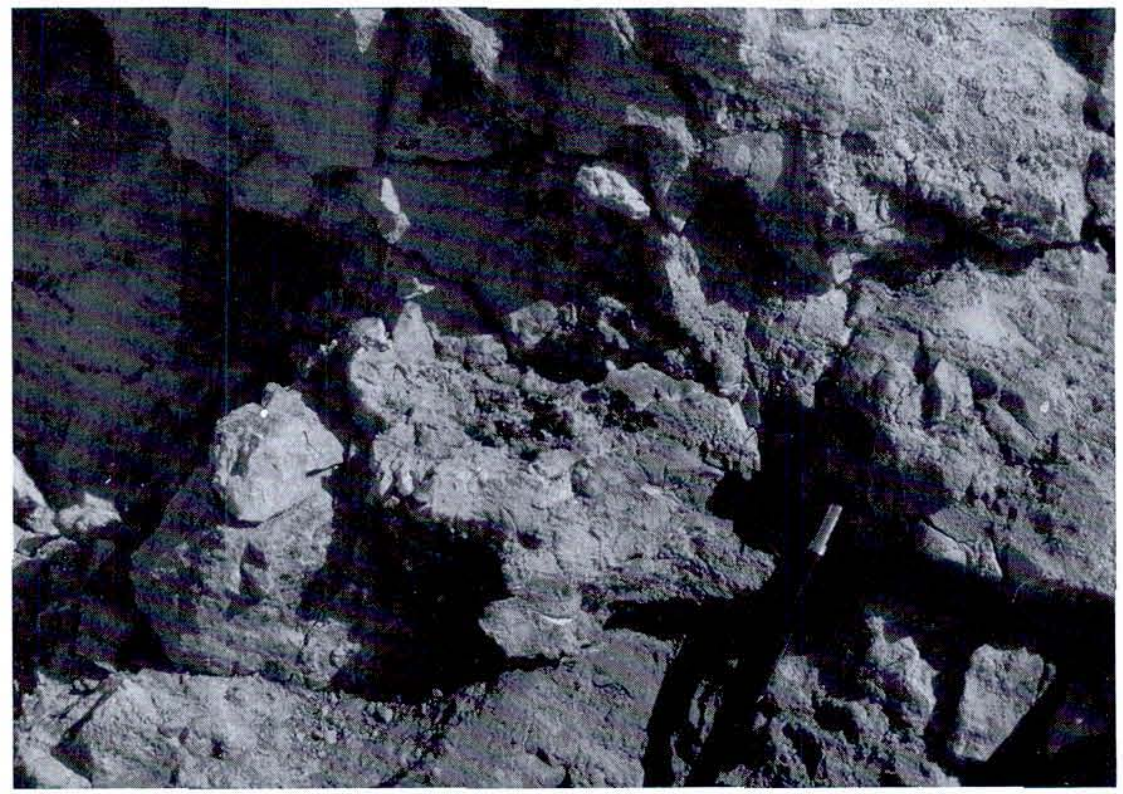

Fig. 5. Bitumen filled vugs in an Upper Permian algal boundstone, Margrethedal.

\section{Evidence of hydrocarbon generation}

Previously, evidence of hydrocarbon generation was presented by Secher \& Steenfelt (1976), who found degraded bitumen in Devonian and Carboniferous rocks from geographically widely separated localities in the south-western part of the study area. Many of the localities mentioned were revisited this summer. The bitumen occurrences are very localized and seem to be related to hydrocarbon generation in the vicinity of major faults or intrusions.

New evidence of hydrocarbon generation includes:

(1) A local discovery of degraded bitumen in an Upper Permian oolitic grainstone at Kap Stosch.

(2) Common occurrences of bitumen in Upper Permian algal boundstone (fig. 5) and Triassic sandstone at Margrethedal. At this locality, the bitumen is associated with hydrothermal minerals such as flourite, dolomite and galena in the limestone. Generation of hydrocarbons probably took place in the Ravnefjeld Formation shales during intrusions of the numerous Tertiary sills in the area.

\section{Discussion}

The investigations in the Devonian mainly focussed on the tectonic and sedimentary history of the basin. It was evident from the 1986 field work (Marcussen et al., 1987 ) and the following analyses that the source potential of the Devonian sequence is very restricted. This was confirmed as only two very thin shaly sequences of restricted lateral extension were found.

The oil potential of the onshore part of the East Greenland basin is apparently confined to the Carboniferous to Cretaceous part of the sequence. Rock Eval analyses of parts of the material collected this year indicate that the potential source rock units identified in the southern part of the area (Surlyk et al., 1986a; Piasecki, 1986, 1987; Marcussen et al., 1987) also have source potential. This is particularly the case for the marine shales of the Upper Permian Ravnefjeld Formation and the Upper Jurassic Bernbjerg Formation. In contrast the Carboniferous lacustrine shales and the thick Cretaceous Aptian - Albian shale sequence have not yet proved to have any source potential.

Potential reservoir units occur throughout the sequence. However, onshore prospects may be found primarily in the Carboniferous to Triassic succession having fluviatile sandstones, carbonate mounds or submarine channel sandstones in stratigraphical positions close to the respective potential source rocks.

Acknowledgements. The Royal Danish Air Force provided transportation to and from Mestersvig, coordinated by Major J. F. Clemmensen. The landing strip at Mesters Vig is kept open by Nordisk Mineselskab on behalf of the Mineral Resources Administration for Greenland. Nordisk Mineselskab also provided facilities and help during mobilization and demobilization in Mestersvig. Flugfélag Norðurlands hf., Island, transported personnel and goods from Mestersvig to Stordal. Unifly, Denmark, provided helicopter transportation during the season with L. Rahm and B. Hvidberg as pilots and $\mathrm{K}$. 
Kristiansen as mechanic. I. K. Olsen and J. Lautrup worked as base personnel while J. Bojesen-Koefoed, J. Halskov, G. S. Nielsen, P. Schiøler and K. Zinck Jørgensen assisted in the field and at base camp. $\mathrm{H}$. Olsen's sedimentological studies in the Devonian are supported by the Carlsberg Foundation. M. Larsen and B. Sikker Hansen helped to prepare the manuscript.

\section{References}

Bendix-Almgreen, S. E., Clack, J. A. \& Olsen, H. 1988: Upper Devonian and Upper Permian vertebrates collected in 1987 around Kejser Franz Joseph Fjord, central East Greenland. Rapp. Grønlands geol. Unders. 140 (this report).

Bütler, H. 1959: Das Old Red Gebiet am Moskusoksefjord. Meddr Grønland 160(5), 188 pp.

Friend, P. F., Alexander-Marrack, P. D., Allen, K. C., Nicholson, J. \& Yeats, A. K. 1983: Devonian sediments of East Greenland VI. Meddr Grønland 206(1), 96 pp.

Koch, L. \& Haller, J. 1971: Geological map of East Greenland $72^{\circ}-76^{\circ}$ N.lat. Meddr Grønland 183, 26 pp.

Malmquist, D. 1932: Zur Kenntnis der oberkarbonischen Sedimente der westlichen Clavering Insel, Ostgrönland. Meddr Grønland 94(6), 28 pp.

Marcussen, C., Christiansen, F. G., Larsen, P.-H., Olsen, H., Piasecki, S., Stemmerik, L., Bojesen-Koefoed, J., Jepsen, H. F. \& Nøhr-Hansen, H. 1987: Studies of the onshore hydrocarbon potential in East Greenland 1986-87: field work from $72^{\circ}$ to $74^{\circ}$ N. Rapp. Grønlands geol. Unders. 135 , 72-81.

Maync, W. 1942: Stratigraphie und Faziesverhältnisse der Oberpermischen Ablagerungen Ostgrönlands (Olim 'Oberkarbon-Unterperm') zwischen Wollaston Forland und dem Kajser Franz Josephs Fjord. Meddr Grønland 115(2) 128 pp.

Maync, W. 1949: The Cretaceous beds between Kuhn Island and Cape Franklin (Gauss Peninsula) northern East Greenland. Meddr Grønland 133(3), 291 pp.

Nielsen, E. 1935: The Permian and Eotriassic vertebrate-bearing beds at Godthaab Gulf (East Greenland). Meddr Grønland 98(1), $111 \mathrm{pp}$.
Piasecki, S. 1986: Initial evaluation of the hydrocarbon potential of central East Greenland. Unpubl. intern. GGU rep., $34 \mathrm{pp}$.

Piasecki, S. 1987: LECO/Rock-Eval screening analysis of the Upper Palaeozoic - Mesozoic sediments of Jameson Land, central East Greenland. Unpubl. intern. GGU rep., 42 pp.

Säve-Söderbergh, G. 1934: Further contributions to the Devonian stratigraphy of East Greenland. Meddr Grønland 96(2), $74 \mathrm{pp}$.

Secher, K. \& Steenfelt, A. 1976: Foreløbig rapport over malmmikroskopisk og mineralogisk undersøgelse af radioaktive mineraliseringer i Randbodal, Østgrønland. Indledning til diskussion af de genetiske forhold. Unpubl. intern. GGU rep., 35 pp.

Surlyk, F. 1977: Stratigraphy, tectonics and palaeogeography of the Jurassic sediments of the area north of Kong Oscars Fjord, East Greenland. Bull. Grønlands geol. Unders 123, $56 \mathrm{pp}$.

Surlyk, F. 1978a: Submarine fan sedimentation along fault scarps on tilted fault blocks (Jurassic - Cretaceous boundary, East Greenland). Bull. Grønlands geol. Unders. 128, 108 pp.

Surlyk, F. 1978b: Mesozoic geology and palaeogeography of Hochstetter Forland, East Greenland. Bull. geol. Soc. Denmark 27, 73-87.

Surlyk, F. 1983: Source rock sampling, stratigraphical and sedimentological studies in the Upper Palaeozoic of the Jameson Land basin, East Greenland. Rapp. Grønlands geol. Unders. 115, 88-93.

Surlyk, F., Hurst, J. M., Marcussen, C., Piasecki, S., Rolle, F., Scholle, P. A., Stemmerik, L. \& Thomsen, E. 1984: Oil geological studies in the Jameson Land basin, East Greenland. Rapp. Grønlands geol. Unders. 120 85-90.

Surlyk, F., Hurst, J. M., Piasecki, S., Rolle, F., Scholle, P. A., Stemmerik, L. \& Thomsen, E. 1986a: The Permian of the western margin of the Greenland Sea - a future exploration target. In Halbouty, M. T. (edit.) Future petroleum provinces of the world. Mem Amer. Ass. Petrol. Geol. 40, 629659.

Surlyk, F., Piasecki, S. \& Rolle, F. 1986b: Initiation of petroleum exploration in Jameson Land, East Greenland. Rapp. Grønlands geol. Unders. 128, 103-121.

\title{
Upper Devonian and Upper Permian vertebrates collected in 1987 around Kejser Franz Joseph Fjord, central East Greenland
}

\author{
Svend Erik Bendix-Almgreen, Jennifer Alice Clack and Henrik Olsen
}

In July and August 1987 a five-man British/Danish vertebrate palaeontological expedition carried out field work on Gauss Halvø and eastern Ymer $\emptyset$ to collect fossil vertebrates from exposures of the Upper Devonian continental and Upper Permian marine deposits. In the context of sampling for vertebrates the Upper
Devonian deposits were last visited in 1955 when one of the writers (SEB-A) assisted the late Dr Eigil Nielsen with field work while the Upper Permian marine deposits have not been examined since Bendix-Almgreen's field work in the Kap Stosch area in the summer of 1967. 